DOI: 10.46340/eppd.2020.7.5.9

\author{
Bohdana Ostrovska, PhD in Law, Senior Researcher \\ ORCID ID: https://orcid.org/0000-0002-1791-7400 \\ V. M. Koretsky Institute of State and Law, Kyiv, Ukraine \\ Expert of UNESCO Chair "Human Rights, Peace, Democracy, \\ Tolerance and International Understanding" at National University \\ of "Kyiv-Mohyla Academy", Ukraine
}

\title{
OUTSIDE OF THE RIGHT TO LIFE: BIOETHICAL PROBLEM OF EMBRYOS DESTRUCTION IN THE ASSISTED REPRODUCTIVE TECHNOLOGIES APPLICATION
}

\begin{abstract}
The legal and bioethical problem of embryos destruction in the assisted reproductive technologies application on the example of the case Evans $v$. the United Kingdom of the European Court of Human Rights is explored in this article. Issues of legal and biological status of human embryos are considered. The important role of the dissenting opinion of the judge of the European Court of Human Rights in the protection of the human right to life before birth is emphasized. It is concluded that the content of the right to life must also be expanded to take into account the bioethical aspects of human rights. The proposals for the basic provisions of the draft Additional Protocol to the Convention on Human Rights and Biomedicine for the Protection of Human Embryos and Fetuses are made.
\end{abstract}

Keywords: assisted reproductive technologies, in vitro fertilization, embryo destruction, consent, right to life, the European Convention, the European Court, bioethics.

A good example that concentrates a number of bioethical problems (primarily legal status of the embryo in vitro ${ }^{1}$ and in utero ${ }^{2}$, rights on the gametes, embryo reduction, etc. $\left.{ }^{3}\right)$ is the case of Evans $v$. the United Kingdom of 07 March $2006^{4}$. According to the case, the applicant Natallie Evans complained about the refusal of implanting her genetically related embryos after breaking up with her partner [J.] (without his consent to fertilization) and further destruction of the embryos, that, in her opinion, constitutes a violation of the right to life in respect of the embryo (Article 2 of the European Convention on Human Rights ${ }^{5}$ ) (hereinafter - the European Convention), as well as the right to respect for privacy and family life (Article 8) and the principle of prohibition of discrimination (Article 14) against herself. Instead, the European Court of Human Rights (hereinafter - the European Court) issued a judgment that there were no violations of the aforementioned articles.

The case originated in an application on 11 February 2005. Since it dealt with the life of embryos the President of the Chamber, under Rule 39 (of the Rules of Court) ${ }^{6}$, decided to indicate to the Government of the respondent State "to take appropriate measures to ensure that the embryos were preserved until the Court ${ }^{7}$ had completed its examination of the case" in the interests of the proper conduct of the proceedings, as well as decided that the application should be given priority treatment, under Rule 41 (para. 5). In its judgment of

\footnotetext{
${ }^{1}$ From Latin - "in glass".

${ }^{2}$ From Latin - "within the womb".

${ }^{3}$ Ostrovska, B. (2017). Bioethical aspects of ratio between reproductive rights of a human being and his right to life in the process of using assisted reproductive technologies. European Political and Law Discourse, 4 (1), 83-90.

${ }^{4}$ Case of Evans v. the United Kingdom, no. 6339/05, ECHR 2006. <http://hudoc.echr.coe.int/eng?i=001-80046> (2020, September, 15).

${ }^{5}$ Convention for the Protection of Human Rights and Fundamental Freedoms 1950 (Council of Europe).

$<$ https://rm.coe.int/1680063765 > (2020, September, 15).

${ }^{6}$ Rules of Court 2019 (European Court of Human Rights) <https://www.echr.coe.int/Documents/Rules_Court_ENG.pdf> (2020, September, 15).

${ }^{7}$ The term "Court" is used in the official text of the decisions of the European Court of Human Rights.
} 
7 March 2006 the Chamber held unanimously, that "there had been no violation of Articles 2 or 14 of the Convention and by five votes to two that there had been no violation of Article 8" (para. 6).

In accordance with Article 43 of the European Convention on 5 June 2006 the applicant submitted a request for referral the case for consideration to the Grand Chamber of the European Court, in response to which on 3 July the President of the European Court decided to continue the preliminary instructions addressed to the respondent. As the case (concerning artificial insemination) concerns "sensitive moral and ethical issues against a background of fast-moving medical and scientific developments, and since the questions raised by the case touch on areas where there is no clear common ground amongst the member States" the European Court emphasized on the wide margin of appreciation that afforded to the respondent State (para. 81).

Arguing its decision on the absence of violation of the right to life and on the alleged violation of Article 2 of the European Convention, the European Court found that "the issue of when the right to life begins comes within the margin of appreciation which the Court generally considers that States should enjoy in this sphere. Under English law, as was made clear by the domestic courts in the present applicant's case, an embryo does not have independent rights or interests and cannot claim - or have claimed on its behalf a right to life under Article 2. There had not, accordingly, been a violation of that provision" (para. 54).

Therefore, for the reasons previously set out by the Chamber, the Grand Chamber considers that "the embryos created by the applicant and J. do not have a right to life within the meaning of Article 2 of the Convention, and that there has not, therefore, been a violation of that provision" (para. 56).

Analysing the provisions of national legislation of the United Kingdom, the European Court concluded that the refusal of the applicant's partner in the further storage of frozen embryos was legitimate, since Human Fertilisation and Embryology Act $1990^{1}$ provides the right of each spouse to withdraw their consent at any time before the implantation of the embryo into the uterus.

In addition, the documents signed by the applicant and her partner concerning the clinic's provision of artificial insemination services in the "storage" column, they both agreed to store artificially created embryos for no more than 10 years. As a result, in 2001, six embryos were created and stored. Though, their implantation into the uterus should have been no earlier than in two years term, since the applicant was performed surgical removal of the ovaries due to the threat of tumor development, which required compliance with this deadline. However, in 2002 the relationship between the applicant and her partner was severed, for that reason he withdrew his consent for further storage of the embryos, in fact, not agreeing to their further implantation.

In examining the circumstances of the case, the European Court found that, having considered the case in a national court of first instance, Judge John Wall justified, that the right to withdraw his or her permission is consistent with the principle of protecting the interests of the unborn child. The Court of Appeal similarly concluded that the applicant's partner gave consent only to the joint course of treatment, and their severance in the relationship should be regarded as the end of their joint treatment. Otherwise, failure to take into account the applicant partner's unwillingness to be a parent would narrow his right to privacy under the European Convention. Thus, the expressed desire for implantation of embryos should be mutual. At the same time, the Court of Appeal, making a decision, stressed that "the ability to give birth to a child gives many women a supreme sense of fulfilment and purpose in life. It goes to their sense of identity and to their dignity". However, "each person has a right to be protected against interference with their private life. That is an aspect of the principle of self-determination or personal autonomy. It cannot be said that the interference with [J.'s] right is justified on the ground that interference is necessary to protect [the applicant's] right, because her right is likewise qualified in the same way by his right. They must have equivalent rights, even though the exact extent of their rights under Article 8 has not been identified" (para. 26).

In addition, according to the report by the Committee for the Study of In vitro Artificial Insemination, which was established in the United Kingdom in 1982 in response to the birth of the first child conceived in this way in 1978, for exploring the social, ethical and legal implications of this achievement, appropriate recommendations were provided and published in 1984, which stated that in case of disagreement neither party may require embryos for further use (implantation) contrary to the will of the other, since "there should be no right of ownership in a human embryo" (para. 10.11). In case of any differences between the couple regarding the possibility of further use and storage of frozen embryos, the Committee recommended that the right of use or disposal of them should pass to the storage authority (para. 10.13), as well as in case of expiry of their term of use (para. 10.10).

\footnotetext{
${ }^{1}$ Human Fertilisation and Embryology Act 1990 (UK Parliament). <https://www.legislation.gov.uk/ukpga/1990/37/contents> (2020, September, 15).
} 
Such considerations have not lost their relevance today, given the existence of similar situations. Moreover, the prolonged cryopreservation of embryos makes it possible to preserve their viability with an aim of further implantation for infertile couples (at child adoption level) in contrast to their destruction. At the same time, there were also proposals at the national level (such as Recommendation report "Human Fertilisation and Embryology: A Framework for Legislation", published in November 1987) concerning necessity to retain only the rights to preserve their viability for the embryo storage organization, but the right to transfer the embryo to the possession and disposal of the third parties carry out solely with the consent of the genetic parents as donors. An important provision of the Human Fertilization and Embryology Act 1990 is the prohibition on withdrawal of consent after implantation of the embryo into a woman's body, that is a guarantee of his further development.

This decision of the European Court based, in particular, on the absence of provisions in the European Convention, that regulate this right to a human being until the moment of the birth. This once again confirms the need to adopt an international legal act, which would set a unified objective position on regulation of the application of assisted reproductive technologies (hereinafter - ART) (including surrogacy, that may be hidden threat of human trafficking for organ, first of all - children and women, as well as forced commercial surrogacy), since there are no international agreements at the international law level, which would express consensus on this issue ${ }^{1}$.

Since the embryos were conceived by mutual consent, that certainly implies the consent of the partner, therefore, further embryonic fate issues should be agreed upon at the time of their agreement with the clinic for in vitro fertilization, especially when the embryos are not implanted immediately in utero, but should be frozen. Currently, the issue of changing the designation of earlier created embryos should not be decided by the European Court which makes the decision on the basis of an analysis of the rules of national law in its comparison with the European Convention.

In order to avoid differences of national legislation, which causes the development of "reproductive tourism" between the States, the issue of maximum allowable number of embryos, created by artificial insemination in vitro, as well as the requirements for their implantation (both a synchronous implantation of all embryos and partial - with further cryopreservation of some of them) should be clearly defined at the international law level. The issues of using non-implanted embryos after divorce of spouses, as well as posthumous reproduction issues (for example, implantation of embryos to the wife after the death of her husband or to the surrogate mother after the death of the wife) should also be clearly regulated.

On the issue of determining the future fate of non-implanted embryos, which have become the subject of controversy, the wishes of both parties are equal. However, in the case if one party is unable to realize parenthood by other means than using of embryos that are the subject of dispute, then preference should be given to the interests of this party over the interests of the other party which wants to avoid reproduction. Moreover, the satisfaction of unilateral request for the destruction of one's own embryos is not a reflection of the balance of interests of the parties to the dispute. In this case embryo transfer to another couple for the purpose of fertilization is an alternative solution since the principle of gifting and preserving life should be the basis for the implementation of ART services, especially for persons who suffering from infertility. It should be an expression of the "margin of appreciation" of States, repeatedly referred by the European Court in bioethical cases, given the lack of international consensus on the application of innovative biomedical technologies to human ${ }^{2}$.

On the basis of established scientific fact on the origin of human life from conception, the consent to use of gametes (male and female) may only be withdrawn until in vitro fertilization (hereinafter - IVF) ${ }^{3}$. Since fertilization to implantation the life of the embryo should be protected by law. These provisions should be fundamental as international de lege ferenda norms on the establishment of legal protection of the interests of the parties and, above all, the life of the embryo in vitro. Otherwise, the life of the embryo in utero would have much more value, that gives grounds for claiming about discrimination against the person based on the place of conception.

\footnotetext{
${ }^{1}$ Seе: Брашовяну, А. (2013). Міжнародний досвід законодавчого регулювання питання використання репродуктивних технологій (включаючи сурогатне материнство). Київ.

${ }^{2}$ Медведєва, М. (2017). Деякі питання біоетики в практиці Європейського суду з прав людини. Сучасні проблеми міжнародного права: Liber Amicorum до 60-річчя проф. М. В. Буроменського. Львів; Одеса: Фенікс, 261-280.

${ }^{3}$ Baía, I., de Freitas, C., Samorinha, C. et al. (2019). Dual consent? Donors' and recipients' views about involvement in decision-making on the use of embryos created by gamete donation in research. BMC Medical Ethics, $20,90$. <https://doi.org/10.1186/s12910-019-0430-6>.
} 
Despite the principle of proportionality of both donor gametes rights, it should agree with the applicant's arguments on special physical and mental load that a woman carries as an egg donor: "The female gamete provider, by contrast, donated eggs, from a finite limited number available to her, after a series of sometimes painful medical interventions designed to maximize the potential for harvesting eggs. In the case of a woman with the applicant's medical history, she would never again have the opportunity to attempt to create a child using her gametes. Her emotional and physical investment in the process far surpassed that of the man and justified the promotion of her Article 8 rights" (para 62).

At the same time, as an exception, in special circumstances (in particular, in case of the physical inability to have a genetically native child - infertility), the right of the person to exercise paternity over the right to autonomy must be taken into account, since one of the main intended use of the ART is providing the possibility of procreation for those who don't have the physical ability to exercise their reproductive rights otherways. Therefore, the issues of the balance of interests of gamete donors on the right to use or destroy them requires consideration of this exceptional circumstance. According to L. Timchenko and V. Kononenko, achieving such a "fair balance" requires from States parties the legislative implementation of all relevant interests in the individual cases and, if necessary, the permission for exceptions to the certain rules"1.

The European Court concluded that the right to respect the desire to have a genetically related child subjects the provisions of Article 8 of the European Convention. Although the boundaries between the state's positive obligations (to apply measures for respect the privacy of individuals even in the area of personal relationships, i.e. the intervention to exercise human rights) and its negative obligations (to refrain from interfering with the privacy and autonomy of the individual) under Article 8 "do not lend themselves to precise definition" (para 75). However, the existence of irreconcilable interests of both parties, regarding the freedom to exercise their rights in the context of that article, violates one party's rights and autonomy while satisfying the other party's personal interests. That is, recognition of the applicant's right to continue the course of treatment independently without a partner will lead to paternity contrary to his will. At the same time, the satisfaction of the other party's request for the destruction of the embryos on the basis of withdrawal of consent will lead to the deprivation of the opportunity to have a genetically related child by the applicant.

Analysing the need of finding a balance between the conflicting rights to which IVF parties (woman and man) may refer under Article 8 of the European Convention, Grand Chamber "does not consider that the applicant's right to respect for the decision to become a parent in the genetic sense should be accorded greater weight than J.'s right to respect for his decision not to have a genetically related child with her" (para. 90).

In Joint dissenting opinion of judges Türmen, Tsatsa-Nikolovska, Spielmann and Ziemele on the balance of interests indicated, that taking into account the specific circumstances of the case (the applicant's health), the rules of national law have deprived the applicant of any possibility of having a genetically related child, unlike her partner, therefore "the application of the 1990 Act in the applicant's circumstances is disproportionate. Because of its absolute nature, the legislation precludes the balancing of competing interests in this particular case... J. will still be able to take a decision to become a parent of his own child, whereas the applicant has had her last chance" (para. 7) ${ }^{2}$. In addition, the judges considered that "the legislation has not struck a fair balance in the special circumstances of the case. Where the effect of the legislation is such that, on the one hand, it provides a woman with the right to take a decision to have a genetically related child but, on the other hand, effectively deprives a woman from ever again being in this position, it inflicts in our view such a disproportionate moral and physical burden on a woman that it can hardly be compatible with Article 8 and the very purposes of the Convention protecting human dignity and autonomy" (para. 13).

Taking into account that the applicant underwent surgery that prevented her to have genetically related children in the future, therefore extracting her gametes (the eggs) for IVF treatment and further fertilizing them with her partner's gametes made it possible to create and consign to storage 6 embryos that was her only opportunity to become a mother and have a genetically related child. Accordingly, her partner $[J$. $]$ was informed about this only opportunity, that gives reason to believe that the applicant acted in good faith in accordance with the law relying on her partner's assurance. The judges consider that the partner has lost the ability to control his gametes since the fertilization of the applicant's egg. "An embryo is a joint product of two people" since he was created using gametes of two individuals, therefore "the act of destroying an embryo also involves destroying

\footnotetext{
${ }^{1}$ Тимченко, Л.Д., Кононенко, В.П. (2012). Баланс конкурирующих интересов в практике судов: международный и национальный аспект. Международное право как основа современного миропорядка. Киев-Одесса: Фенікс, 491.

${ }^{2}$ Joint dissenting opinion of judges Türmen, Tsatsa-Nikolovska, Spielmann and Ziemele 2007 (European Court of Human Rights). <http://hudoc.echr.coe.int/eng?i=001-80046> (2020, September, 15).
} 
the applicant's eggs" (para. 8). Therefore, due to the particular circumstances of the case, the judges emphasized the superiority of the applicant's interests over the interests of her partner, and admitted that rejection of this fact by the United Kingdom's authorities is a violation of the requirements of Art. 8 of the European Convention. (para. 9). Consequently, the balance of interests cannot take place when a man will be able to have genetically related children and a woman will be deprived of this opportunity forever.

Certainly, donors of gametes have a preferential right to resolve the issue (the dispute) for their subsequent use. Adherence to the principle of consent in matters of ART should reflect specific actions (e.g. the written consent) or, otherwise, should reflect as the presumption of consent, provided for by law. Voluntary implementation for certain practices of assisted reproduction (e.g., consent to embryo implantation) is a basic principle. But a decision on this issue should also comply with the interests of the unborn baby, which cannot be regarded as property (both in the context of the European Convention and in the general sense).

The circumstances of this case, which raise a complex of ethical issues, require deeper consideration than "the mere question of consent in a contractual sense" (para. 10), since the values that are relevant to this case (above all, life as the highest value) and problems that arise (obstruction to the person's exercise of his reproductive function), speaking about the specific situation of the applicant, have more weight rather than the formal binding approach used in making the decision in this case.

Usually, most of the decisions on such bioethical cases adjudicate on a simplistic mechanical basis, that is, referring to the lack of consensus among European countries, which determines the wide margin of appreciation of States on these sensitive issues. As indicated in paragraph 81 of the judgment: "... since the use of IVF treatment gives rise to sensitive moral and ethical issues against a background of fast-moving medical and scientific developments, and since the questions raised by the case touch on areas where there is no clear common ground amongst the member States, the Court considers that the margin of appreciation to be afforded to the respondent State must be a wide one". But at the same time "that margin of appreciation should not prevent the Court from exercising its control, in particular in relation to the question whether a fair balance between all competing interests has been struck at the domestic level", including public and private ones (para. 12).

Unfortunately, the unanimous decision of the European Court on the absence of a violation of Article 2 of the European Convention suggests that the European Court avoided considering the recognition of the ontological essence of human without including biomedical facts as an evidence in the case. In particular, the biological status of the human embryo means that he is neither merely a complex of cells or a fertilized egg, is not identical with an organ or its part, nor is part of the mother's body (at least because it can vary by blood type, $\mathrm{Rh}$ factor and even more by gender in contradistinction to maternal organism), based on the fact that he has a unique combination of genes, which distinguishes him from any cell of the body of his mother or father. In this sense the parents have the "ownership" of the embryo only in the context of care and protection of him, as well as responsibilities, that is, as a complex of parental rights including, inter alia, presupposes the inheritance rights of the embryo as a child. Therefore, the ontological status of a human embryo is equivalent to the status of a person already born, as it presupposes his dignity as a human being on a general basis. On this basis, it is inadmissible to justify the lack of the right to human life at the embryonic stage of development - the embryo, based on the substitution of his ontological status by a functional one. That is, referring, in particular, to such characteristics as consciousness, autonomy, rationality, etc., that are inherent in the person in the further stages of its development. Such a substitution leads to false conclusions about the non-recognition of a personal existence of human (which means - his or her right to life) which is in a vegetative state or coma, for example, after a brain injury that has led to disorders of consciousness ${ }^{1}$.

According to V. Kononenko "stare decisis limits the dynamic interpretation, and the last one that does not allow it to stand firm in its precedents, which may become obsolete and cease to comply with the objectives of the Convention over time", but "...given the dynamic interpretation of the 1950 Convention by the European Court of Human Rights development of doctrine and law in this direction, it is possible to predict that over time the practice of the ECtHR will change accordingly, that will entail a review of the relevant rules of domestic law up to the constitutional provisions on the right to life" ${ }^{2}$.

\footnotetext{
${ }^{1}$ Ostrovska, B. (2019). Should euthanasia be a solution to the problem of "decent" death? (on the example of the case Lambert and others v. France). Actual problems of international relations, 141, 57-66.

<https://doi.org/10.17721/apmv.2019.141.1.57-67>.

${ }^{2}$ Кононенко, В. (2019). Практика Європейського суду з прав людини як «живе право» та конституційне право на життя. Правова держава, 35, 92. <https://doi.org/10.18524/2411-2054.2019.35.181338>>
} 
In this context Judge D. Dedov (case of Parillo v. Italy of 27 August 2015) ${ }^{1}$ noted, that "the embryo's existence is a condition for a human being's development" (para. 3), and therefore "the principle of respect for the embryo's right to life means that the judicial decision cannot be limited by reference to the margin of appreciation" (para. 4) ${ }^{2}$. Anyway "the embryo's life cannot be sacrificed for the purpose of inter-State competition in biomedicine" (para. 8). Moreover "the embryo's right to life cannot be called into question by the fact that, until implantation, its potential for development is something that can be maintained artificially, because any such new technology is a natural development created by human beings" (para. 9). Thus, the issue of threat to his life may completely change "the judicial approach in accordance with the Court's role in interpreting the Convention, including the positive obligation of the State to safeguard the beginning of life" (para. 3) $)^{3}$. In his opinion "from the point of view of humanity ... for the sake of preservation of the embryo's potential, it is vital to implant it if another woman would like to become a mother by that method" (para. 6) .

Such a proposal, implemented through anonymous donation, is a viable alternative to the destruction of "unnecessary" embryos, either due to the death of one or both spouses, and in case of expiration of their storage, or as a result of their preimplantation reduction.

Conclusions. The answer to the question of when a human embryo has the right to life, and therefore to be human, will allow to determine the legal grounds for manipulation with human gametes and embryos, the possibility or impossibility of their selective reduction at will, as well as to determine the further participation of non-implanted ("spare") gametes and embryos, particularly for their use in research purposes. The definition of this point should be based on scientific biological data about human, which should serve as a basis for determining the legal status of human at the prenatal stage of his development.

The modern development of scientific and technological progress implies the expansion of opportunities and human rights, and therefore the urgent task of legal science is to evolve the law with new and constantly changing living conditions ${ }^{5}$. Accordingly, the law should be interpreted in accordance with these changes.

At present, the scope of fundamental human rights, in particular the right to life, also needs to be changed, both quantitatively and qualitatively, to cover all the conditions that affect it and to protect them effectively. Otherwise, if the right to life is not expanded to include these aspects, it will not soon be able to cover all aspects, including bioethical, which relate directly to human life, above all its existence as a biosocial being. This is a real challenge for lawyers.

Now the right to life itself can no longer be fully protected in the classical sense as it has been since the adoption of the Universal Declaration of Human Rights in 1948. Therefore, the content of the right to life must also be expanded to take into account the bioethical aspects of the evolution of human rights.

Therefore, on the basis of the study and in accordance with Article 32 of the Oviedo Convention, we offer the following proposals for the basic provisions of the draft Additional Protocol to the Convention on Human Rights and Biomedicine for the Protection of Human Embryos and Fetuses.

1. The dignity of each person as a biosocial being, representative of the genus homo sapiens should be recognized since the beginning of his life - from conception.

2. Everyone is unique because has a unique genetic code from the moment of conception, that cannot be the basis for any discrimination against him or her.

3. The dignity of a human embryo implies that he has such rights as: the right to human identity ("the right" to be called a human), the right to life (that includes, in particular, the right to birth), the right to development (as an individual).

4. The use of human fetal materials (anatomical materials of a dead human embryo (fetus)) for the purpose of transplantation of organs, tissues, cells or blood is prohibited.

5. The creation of human embryos by assisted reproductive technologies (primarily by the method of cloning) for the purpose of their further use as donor biomaterial, in particular for the production of stem cells, is prohibited.

\footnotetext{
${ }^{1}$ Case of Parillo v. Italy, no. 46470/11, ECHR 2015. <http://hudoc.echr.coe.int/eng?i=001-157263> (2020, September, 15).

${ }^{2}$ Concurring Opinion of Judge Dedov 2015 (European Court of Human Rights). <http://hudoc.echr.coe.int/eng?i= 001-157263> (2020, September, 15).

${ }^{3}$ Concurring Opinion of Judge Dedov 2015 (European Court of Human Rights). <http://hudoc.echr.coe.int/eng?i= 001-157263> (2020, September, 15).

${ }^{4}$ Concurring Opinion of Judge Dedov 2015 (European Court of Human Rights). <http://hudoc.echr.coe.int/eng?i= 001-157263> (2020, September, 15).

${ }^{5}$ Ostrovska, B. (2018). International Legal Aspects of Human Life Protection in the Process of Application of Innovative Biomedical Technologies Science and Innovation, 14 (5), 25-33. <https://doi.org/10.15407/scin14.05.025>.
} 
6. The destruction of human embryos in vitro, as well as in utero, for the purpose of using them as donor biomaterials, is prohibited.

7. The creation of human embryos by assisted reproductive technologies for the purpose of conducting scientific experiments on them is prohibited.

8. The preimplantation human embryos in vitro enjoy the same protection as the human embryos in utero.

9. All embryos in virto that are subject to cryopreservation should continue to be used for their intended purpose - for implantation for further development in utero.

10. Voluntary application of assisted reproduction methods implies compliance with the principle of consent. Consent must be confirmed in writing.

11.Everyone has the right to freeze his or her own gametes for further artificial insemination by various methods of assisted reproductive technology for the purpose of procreation.

12. Consent to use gametes (male and female) may only be withdrawn until in vitro fertilization. From the moment of fertilization to implantation, the life of the embryo must be protected by law.

13.Donors of gametes have a preferential right to decide the issue (dispute) regarding their further use.

14. Any decision regarding the life and health of the embryo must be based on respect for his dignity, as well as for the rights and interests of the embryo as a prenatal child.

15.The human embryo cannot be considered in the context of the concept of property. Therefore, with regard to the embryo, its parents (biological or factual) have a set of parental rights exclusively in the context of care and protection, which, in particular, implies that the embryo has hereditary rights as a child, as well as responsibility for his life and health.

16.In resolving the issue of the future use and disposal of unplanned embryos, which are the subject of the dispute, the wishes of both parties are equal. However, if one party does not have the ability to realization of paternity by other means than the use of the embryos which are the subject of the dispute, then the priority should be given to the interests of that party over the interests of the other party which wants to avoid reproduction. In addition, the unilateral request to destroy one's own embryos does not reflect the balance of interests of the parties. Preference is given to preserving the life of the embryo, since the principle of donation and preservation of life should be the basis for providing assisted reproductive technologies services, especially for people suffering from infertility.

17.For the sake of preserving life potential of human embryos in the case of divorce, death, incapacity of one or both of the spouses, as well as by reason of expiration of their storage, embryo implantation in utero through the embryo donation program for persons who suffering from infertility is a preferred alternative to their destruction.

18.The manipulations with human genetic material, primarily germline (heritable) and somatic engineering, cell transplantation and xenotransplantation, are limited to therapeutic, diagnostic or prophylactic purposes.

19. The experimentation and manipulation with gametes and human embryos with difficultly predicted biological and social consequences that lead to changes in the genome of the human organism as a result of the combination of genetically heterogeneous cells that threaten the future generations, in particular, experiments and manipulations aimed at creation interspecific chimeras and hybrids, editing the human genome for nonmedical purposes, including by transgenesis, genetic or epigenetic transformation of zygote_(fertilized egg) or its biological sources, as well as the creation of human ectogenesis technology, are prohibited.

20.The implementation of biotechnological "improvement" of the physical or intellectual characteristics of the human through the application of innovative technologies and gene modification not for therapeutic goals is prohibited.

\section{References:}

1. Convention for the Protection of Human Rights and Fundamental Freedoms 1950 (Council of Europe). <https://rm.coe.int/1680063765> (2020, September, 15). [in English].

2. Convention for the Protection of Human Rights and Dignity of the Human Being with regard to the Application of Biology and Medicine: Convention on Human Rights and Biomedicine 1997 (Council of Europe). <https://www.coe.int/en/web/conventions/full-list/-/conventions/treaty/164> (2020, September, 15). [in English].

3. Rules of Court 2019 (European Court of Human Rights). <https://www.echr.coe.int/Documents/Rules_Court_ENG.pdf> (2020, September, 15). [in English].

4. Case of Evans v. the United Kingdom, no. 6339/05, ECHR 2007. <http://hudoc.echr.coe.int/eng?i=001-80046> (2020, September, 15). [in English]. 
5. Case of Parillo v. Italy, no. 46470/11, ECHR 2015. <http://hudoc.echr.coe.int/eng?i=001-157263> (2020, September, 15). [in English].

6. Joint dissenting opinion of judges Türmen, Tsatsa-Nikolovska, Spielmann and Ziemele 2007 (European Court of Human Rights). <http://hudoc.echr.coe.int/eng?i=001-80046> (2020, September, 15). [in English].

7. Concurring Opinion of Judge Dedov 2015 (European Court of Human Rights) $<$ http://hudoc.echr.coe.int/eng?i=001-157263> (2020, September, 15). [in English].

8. Human Fertilisation and Embryology Act 1990 (UK Parliament). <https://www.legislation.gov.uk/ukpga/1990/37/contents> (2020, September, 15). [in English].

9. Ostrovska, B. (2017). Bioethical aspects of ratio between reproductive rights of a human being and his right to life in the process of using assisted reproductive technologies. European Political and Law Discourse, vol. 4 (1). 83-90. [in English].

10. Ostrovska, B. (2018). International Legal Aspects of Human Life Protection in the Process of Application of Innovative Biomedical Technologies. Science and Innovation, no. 14 (5), 25-33. $<$ https://doi.org/10.15407/scin14.05.025> [in English].

11. Ostrovska, B. (2019). Should euthanasia be a solution to the problem of "decent" death? (on the example of the case Lambert and others v. France). Actual problems of international relations, vol. 141, 57-66. $<$ https://doi.org/10.17721/apmv.2019.141.1.57-67>_[in English].

12. Kononenko, V. (2019). Praktyka Yevropeiskoho sudu z prav liudyny yak «zhyve pravo» ta konstytutsiine pravo na zhyttia. [Practice of the European Court of Human Rights as a "living right" and a constitutional right to life]. Pravova derzhava [Constitutional state], iss. 35. 89-95. [in Ukrainian].

13. Medvedieva, M. (2017). Deiaki pytannia bioetyky v praktytsi Yevropeiskoho sudu z prav liudyny. [Some issues of bioethics in the practice of the European Court of Human Rights]. Suchasni problemy mizhnarodnoho prava: Liber Amicorum do 60-richchia prof. M. V. Buromenskoho [Contemporary problems of international law: Liber Amicorum to the 60th anniversary of prof. M. V. Buromensky]. Lviv; Odesa: Feniks, 261-280. [in Ukrainian].

14. Tymchenko, L.D., Kononenko, V.P. (2012). Balans konkuryruiushchykh ynteresov v praktyke sudov: mezhdunarodnыi y natsyonalnыi aspekt [Balance of competing interests in the practice of courts: international and national aspects]. Mezhdunarodnoe pravo kak osnova sovremennoho myroporiadka [International law as the basis of the modern world order]. Kyiv-Odesa: Feniks. [in Russian].

15. Baía, I., de Freitas, C., Samorinha, C. et al. (2019). Dual consent? Donors' and recipients' views about involvement in decision-making on the use of embryos created by gamete donation in research. BMC Medical Ethics. 20, 90. <https://doi.org/10.1186/s12910-019-0430-6> [in English].

16. Brashovianu, A. (2013). Mizhnarodnyi dosvid zakonodavchoho rehuliuvannia pytannia vykorystannia reproduktyvnykh tekhnolohii (vkliuchaiuchy surohatne materynstvo) [International experience in the legislative regulation of the use of reproductive technologies (including surrogacy)]. Kyiv. [in Ukrainian].

17. Clarke, R. (2017). The "Conscience of Europe?»: Navigating Shifting Tides at the European Court of Human Rights. Kindle Edition. Vienna. [in English]. 